\title{
Lyophilized Escherichia coli-based cell-free systems for robust, high-density, long-term storage
}

\author{
Mark Thomas Smith, Scott D. Berkheimer, Christopher J. Werner, and Bradley C. Bundy \\ Department of Chemical Engineering, Brigham Young University, Provo, Utah
}

BioTechniques 56:186-193 (April 2014) doi 10.2144/000114158

Keywords: in vitro transcription / translation; cell-free protein synthesis; lyophilization; cell-extract preparation; cell-free energy system; GFP reporter protein

Supplementary material for this article is available at www.BioTechniques.com/article/114158.

Cell-free protein synthesis (CFPS) is a versatile tool for rapid recombinant protein production and engineering. One drawback of cell-free technology is the necessity to store the major components-cell extracts and energy systems-below freezing in bulky aqueous solutions. Here we describe simple methods for lyophilizing extracts and preparing powdered energy systems for CFPS. These techniques allow for high-density storage of cell-free systems that are more robust against temperature and bacterial degradation. Our methods have the potential to decrease storage expenses, allow for longer shelf-life of cell extracts at room temperature, and enable durable portable protein production technologies.

Cell-free protein synthesis (CFPS) is a powerful in vitro transcription/translation tool for rapid and efficient production of recombinant proteins. Compared with in vivo protein production, directly accessible cell-free systems provide superior control over the synthesis environment, higher product selectivity, and faster expression of recombinant genes (1-3). These attributes make cell-free technology an excellent platform for high-throughput recombinant expression and synthetic biology technologies $(1,4-8)$. Exploiting the benefits of CFPS, myriad proteins have been produced, such as virus-like particles $(9,10)$, proteins containing unnatural amino acids (11-13), cytotoxic proteins (9), and a variety of biocatalytic enzymes $(14,15)$.

CFPS has been successfully demonstrated with biochemical machinery extracted from many different organisms and cells types, such as wheat-germ, rabbit reticulocytes, insects, yeast, and HeLa cells $(5,16)$. In this work, we focus on the most prevalent, least expensive, and generally highest yielding cell-free system, which is based upon Escherichia coli extract (5).

Prepared cellular extracts for CFPS are commonly stored at $-20^{\circ} \mathrm{C}$ or $-80^{\circ} \mathrm{C}$ prior to use in order to maintain protein synthesis viability $(17-20)$. This necessitates a fairly significant capital equipment investment in the form of low or ultralow temperature freezers, their maintenance, emergency backup freezers, and emergency backup power. These storage considerations are particularly cumbersome when stockpiling large quantities of extract for applications such as rapid vaccine and/or therapeutic production in response to a pandemic. A further limitation of storing the CFPS extracts below freezing temperatures is the inability to easily transport for mobile use applications.

One possibility for improving CFPS extract storage efficiency and utility is to lyophilize the extracts. Lyophilizing or freeze-drying simple protein solutions is a commonplace process to remove the volatile liquids, leaving behind a protein powder. This technique reduces the storage volume and is thought to slow the rate of protein degradation. We hypothesized that lyophilizing E. coli cell extracts would similarly reduce storage volume and potentially allow for longer shelf-life at temperatures above $-80^{\circ} \mathrm{C}$. Lyophilized cell-free systems are commercially available, and previous studies have reported successful synthesis of various proteins using rehydrated lyophilized extracts (21-25). However, a straightforward method to produce a lyophilized E. coli-based cell-free system has yet to be detailed in literature. Furthermore, the impact of lyophilization and storage at non-standard temperatures on protein synthesis performance has yet to be described. Here we report a straightforward method for lyophilizing $E$. coli extract for CFPS using standard machinery. The lyophilized extracts allow for higher density storage and maintain a higher protein synthesis viability at non-standard storage temperatures than aqueous extracts. This simple method provides a viable and convenient alternative to traditional storage strategies by reducing storage costs, protecting extract viability and promoting CFPS accessibility.

\section{Method summary:}

Our method for lyophilizing Escherichia coli extracts allows for dried cell extracts to be stockpiled more densely than standard aqueous extracts while maintaining viability for cell-free protein synthesis (CFPS). Dried cell extracts stored at room temperature retain protein synthesis viability 60 days after aqueous extracts are effectively rendered useless by degradation and contamination. This method has the potential to decrease extract storage expenses, allow for longer shelf-life of cell extracts at room temperature, and enable durable portable protein production technologies such as pharmacy-on-a-chip microfluidic devices. 


\section{Materials and methods}

Cell extract preparation

Cells were grown and extracts were prepared as previously described $(3,26)$. All growth stages were performed at $37^{\circ} \mathrm{C}$ in LB media with shaking at $280 \mathrm{rpm}$. Briefly, Escherichia coli strain BL21-Star (DE3) (Life Technologies, Carlsbad, CA) was inoculated overnight in $5 \mathrm{~mL}$ volumes. Overnight growths were transferred to $500 \mathrm{~mL}$ baffled shake flasks containing $100 \mathrm{~mL}$ media. The intermediate grow ths were monitored to an $\mathrm{OD}_{600}$ of 2 and transferred to $2.5 \mathrm{~L}$ Tunair shake flasks (IBI Scientific, Peosta, IA) containing $1 \mathrm{~L}$ of media. Growths were induced with $1 \mathrm{mM}$ IPTG (GoldBio, St Louis, MO) at an $\mathrm{OD}_{600}$ of $0.4-0.7$ and grown until mid- to late-log phase (an $\mathrm{OD}_{600}$ of 2.0 in this work). Cells were harvested, washed, homogenized, and prepared using the streamlined method described previously $(3,27)$.

\section{Lyophilization of extracts}

Three extract types were lyophilized: $(i)$ standard extract $\left(x S_{T} D_{\text {lyo }}\right),(i i)$ extract supplemented with $0.05 \mathrm{~g}$ per $\mathrm{mL}$ sucrose as a lyoprotectant $\left(\mathrm{xSUC}_{\mathrm{lyo}}\right)$, and (iii) a ready-to-use mixture of extract and small molecules necessary for phosphoenolpyruvate-energized CFPS ([xSTD+ePEP] $\left.{ }_{\text {lyo }}\right)$. Lyophilization took place in $5 \mathrm{~mL}$ volumes as follows: Samples were loaded into $70 \mathrm{~mL}$ cylindrical glass vials for shell freezing in a $-40^{\circ} \mathrm{C}$ ethanol bath (Just-ATilt Shell Freezer Chiller SF-4Az, FTS Systems, Warminster, PA) and incubated for a minimum of $5 \mathrm{~min}$. Vials were transferred to the freeze dryer (Flexi-dry MP, FTS Systems) for 20 min periods. The operating conditions of the freeze dryer were $-60^{\circ} \mathrm{C}$ and $<120$ mTorr, with a $19^{\circ} \mathrm{C}-20^{\circ} \mathrm{C}$ ambient temperature. At the end of each 20 min drying period, vials were placed in the $-40^{\circ} \mathrm{C}$ shell freezer for $1 \mathrm{~min}$ and subsequently replaced onto the freeze dryer. Lyophilization continued in this manner until at least $95 \%$ of the estimated water mass was lost (typically 3 cycles), at which time the vials were chilled on the shell freezer for $1 \mathrm{~min}$, then placed back on the freeze dryer for an additional $60 \mathrm{~min}$ to provide for removal of the more tightly interacting water molecules. Lyophilized product was gently ground using a chemical spatula in a glass vial, aliquoted by mass, and stored in sealed microcentrifuge tubes.

\section{Energy systems}

An aqueous phosphoenolpyruvate-based energy system (ePEP ${ }_{\text {aqu }}$ ) was employed as

Table 1. Extract and energy systems

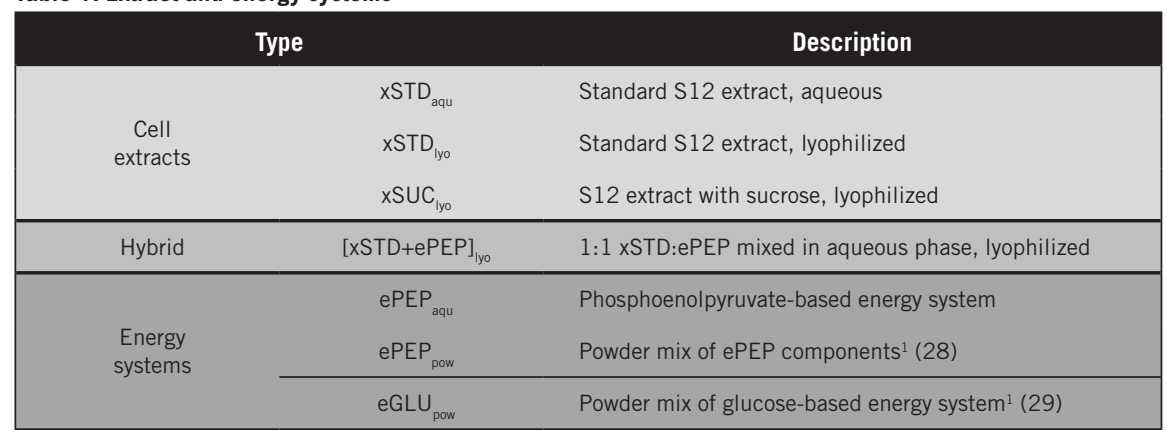

The 19 amino acids, putrescine and spermidine were not included in this powdered mix, but added as separate solutions to the CFPS reactions, as specified in the Supplementary Material.

the primary aqueous energy source for CFPS reactions, as previously described (28). The powdered versions of the ePEP energy system $\left(\mathrm{ePEP}_{\text {pow }}\right)$ and a glucosebased energy system $\left(\mathrm{e}^{\mathrm{pow}} \mathrm{GU}_{\text {pow }}\right)$ were used with slightly adapted reagent amounts as indicated below (29). ePEP ${ }_{\text {pow }}$ contained $0.137 \mathrm{~g}$ of phosphoenolpyruvate (PEP), $0.0328 \mathrm{~g}$ of ammonium glutamate, 0.711 $\mathrm{g}$ of potassium glutamate, $0.0099 \mathrm{~g}$ of potassium oxalate, $0.0044 \mathrm{~g}$ of $\mathrm{NAD}$, $0.0041 \mathrm{~g}$ of CoA, $0.0136 \mathrm{~g}$ of ATP, 0.0091 $\mathrm{g}$ of CTP, $0.090 \mathrm{~g}$ of GTP, $0.0095 \mathrm{~g}$ of UMP, $0.0034 \mathrm{~g}$ folinic acid, and $0.0017 \mathrm{~g}$ of tRNA. eGLU ${ }_{\text {pow }}$ contained $0.1081 \mathrm{~g}$ of glucose, $0.0328 \mathrm{~g}$ of ammonium glutamate, $0.5284 \mathrm{~g}$ of potassium glutamate, $0.0348 \mathrm{~g}$ of dibasic potassium phosphate, $0.0044 \mathrm{~g}$ of NAD, $0.0040 \mathrm{~g}$ of CoA, $0.0094 \mathrm{~g}$ of AMP, $0.0063 \mathrm{~g}$ of CMP, $0.0070 \mathrm{~g}$ of GMP, 0.0063 $\mathrm{g}$ of UMP, $0.0007 \mathrm{~g}$ of folinic acid, and $0.001706 \mathrm{~g}$ of tRNA. A separate solution of amino acids and a separate solution of spermidine and putrescine were prepared. The spermidine and putrescine were kept separate due to their extremely hydrophilic nature. Once all componentsexcluding amino acid mix and spermidine/ putrescine mix-were weighed out, they were combined in a $15 \mathrm{~mL}$ conical tube and mixed until homogeneous. The powder energy mixes were divided into carefully weighed aliquots ranging from 0.04 to $0.06 \mathrm{~g}$. When suspended in water for CFPS reactions, 4.157 and $5.377 \mathrm{~mL}$ water per gram powder were added to the PEP and glucose energy sources, respectively. The hydration volumes $(\mathrm{mL}$ water per gram energy powder) were evaluated such that the final density of powdered components in hydrated powder systems equaled the density of components in prepared aqueous systems (Supplementary Material).

\section{Rehydrating extracts and} cell-free protein synthesis DC assays (Bio-Rad, Hercules, CA) were performed on samples of untreated aqueous extract and rehydrated extract following the manufacturer's specifications with BSA as the control protein. Lyophilized extract was rehydrated in water according to the optimal ratio determined in the DC assay (Supplementary Material).

Cell-free protein synthesis reactions were performed on each extract type as previously described (30). In brief, reactions contained $25 \% \mathrm{v} / \mathrm{v}$ extract, $25 \% \mathrm{v} / \mathrm{v}$ energy source, 12 $\mathrm{nM}$ plasmid encoding the GFP reporter protein (pY71-sfGFP), and an optimized magnesium glutamate concentration (in this study: $9 \mathrm{mM}$ ). Reagents were combined in microcentrifuge tubes and pipetted into a 96-well flat-bottom opaque plate in $20 \mu \mathrm{L}$ aliquots as droplets in the center of each well. After the wells were sealed, the plate was incubated for $3 \mathrm{~h}$ at $37^{\circ} \mathrm{C}$. Following the reaction, $45 \mu \mathrm{L}$ water was added to each well to dilute the reaction over the bottom surface of the well. Resulting GFP fluorescence was measured using a Synergy $\mathrm{Mx}$ microplate reader (BioTek Instruments, Inc., Winooski, VT), and protein yield was determined using a linearly correlated calibration curve, as previously detailed (26).

\section{Bacterial contamination}

To monitor for potential bacterial contamination of the extracts, liquid extracts or lyophilized extracts rehydrated with sterile ultrapure water were diluted in sterile SOC media and plated on LB Agar Miller plates. Plates were incubated for $24 \mathrm{~h}$, at which point colonies were counted.

\section{Results and discussion}

Cell-free protein synthesis (CFPS) affords many benefits over in vivo synthesis systems, such as open access to the synthesis environment, rapid expression of recombinant PCR-products, and easy application of in vitro synthetic biology. An additional advantage of CFPS is that cell extracts can be produced in large batches and stockpiled for future use (31). However, the extract is traditionally stored at $-80^{\circ} \mathrm{C}$ to 
maintain viability, increasing the storage expense and complicating transport of the extract. Here we demonstrate that straightforward lyophilization of $E$. colibased CFPS extracts (i) significantly reduces storage volume, (ii) stabilizes the extract at higher than ideal storage temperatures, and (iii) decreases bacterial contamination. We also propose and demonstrate that powdered energy systems may be utilized to create a CFPS system that can be stored at high density and easily transported.

$E$. coli cell extracts (Table 1) were prepared as reported previously in preparation for lyophilization (26). Two lyophilized extracts types were prepared: (i) standard extract (xSTD lyo $_{\text {yo }}$ ) and (ii) standard extract with sucrose as a potential lyoprotectant $\left(\mathrm{xSUC}_{\mathrm{lyo}}\right)$. The total mass loss was measured directly and percentage water loss was calculated based on DC assay analysis (Supplementary Material), as seen in Figure 1, $A$ and $B$. In all cases, drying removed more than $97 \%$ of the estimated original liquid content from the extracts. The removal of the majority of liquid content immediately reduced the storage volume over 2 -fold and storage mass over 9-fold.

Lyophilized extracts were ground into powders to promote homogeneity and then aliquoted by mass for storage at $-80^{\circ} \mathrm{C},-20^{\circ} \mathrm{C}, 4^{\circ} \mathrm{C}$, and $27^{\circ} \mathrm{C}$. Each lyophilized extract had a unique consistency. $x S_{\text {TDo }}$ had the consistency of well-milled wheat flour and was easily ground into a fine homogenous powder. The fine powder was easily compressed, allowing for 2-3 times the storage density of liquid extract. $\mathrm{xSUC}_{\mathrm{lyo}}$ formed sticky heterogeneous granules, making it somewhat difficult to achieve homogeneity and compressed storage.

In preparation for cell-free reactions, extract powders were suspended in sterile ultrapure water. To establish a baseline for rehydration, $\mathrm{x} S \mathrm{TD}_{\mathrm{lyo}}$ was rehydrated at multiple levels, and the DC assay was used to determine the volume-to-mass ratio corresponding to a protein density equivalent to that of $\mathrm{xSTD}_{\text {aqu }}$ (Supplementary Material). From this baseline, the rehydration volume:mass ratio was established for $\mathrm{xSTD}_{\text {lyo }}$ and calculated for $\mathrm{xSUC}_{\text {lyo }}$ (Supplementary Material).

Extracts were tested for protein-synthesis viability over extended storage times with the results displayed in Figure 2. Notably, $\mathrm{xSTD}_{\text {aqu }}$ performed equally well at -80 and $-20^{\circ} \mathrm{C}$ over the span of 90 days, suggesting that $-80^{\circ} \mathrm{C}$ storage may not be required for long-term viability of CFPS extracts. Indeed, even at $4^{\circ} \mathrm{C}, \mathrm{xSTD}$ aqu maintained effectively all of its activity through 30 days. When stored at $27^{\circ} \mathrm{C}, \mathrm{xSTD}_{\mathrm{aqu}}$ exhibited exponential decay in synthesis performance with effectively no activity by day 60 .

$\mathrm{xSD}_{\text {lyo }}$ and $\mathrm{xSUC} \mathrm{C}_{\text {lyo }}$ initially maintained an average $85 \%$ of the protein synthesis viability of $\mathrm{xSTD}$ aqu. Extract viability was retained when stored at $-80^{\circ} \mathrm{C}$, while increasing storage temperatures corresponded to increasing extract degradation rates. Notably, $\mathrm{xSTD}_{\text {lyo }}$ and $\mathrm{xSUC}_{\text {lyo }}$ stored at room temperature maintained about $20 \%$ protein synthesis viability at day 90 . In contrast, $\mathrm{XSTD}_{\text {aqu }}$ stored at room temperature retained less than $2 \%$ viability by day 30 . In short, the lyophilized extracts retained significantly higher protein synthesis viability than the liquid extracts when stored for more than 30 days above freezing.
The addition of sucrose as a lyoprotectant to extracts prior to lyophilization did not appear to be beneficial (Figure 2). Sucrose and other protein lyoprotectants theoretically stabilize proteins from becoming denatured during the drying and rehydration process (32). However, lyoprotectants are typically utilized to protect purified proteins in solutions that contain one or a few different types of proteins. In the case of extracts, the complex mixture of proteins and other small molecules in solution may contain components that fill the role of stabilizing proteins during drying, making the addition of sucrose unnecessary.

To identify potential causes of lost extract viability at higher storage temperatures, we examined bacterial contamination. Lysis efficiency using a high-pressure homogenizer such as that used for this work has been reported to be $99.9996 \%$ (26). Prior to lysis, cell concentrations are approximately 600 billion per $\mathrm{mL}$, thus even at $99.9996 \%$, prepared extracts can have upwards of 2.4 million cells per $\mathrm{mL}$ extract. Bacterial contamination was measured in colonies per $\mu \mathrm{L}$ extract plated (Supplementary Figure S2). Regardless of storage conditions, $x$ STD $_{\text {aqu }}$ had the highest a mount of contamination, with an effective cell lysis efficiency of $99.99998 \%$ for $\mathrm{xSTD}$ aqu stored at $-80^{\circ} \mathrm{C}$. After 14 days, $x \mathrm{STD}_{\text {aqu }}$ stored at room temperature was too contaminated to quantify accurately, and total CFPS viability dropped significantly, suggesting that bacterial growth likely played a role in degrading the extract. In contrast, $\mathrm{xSTD}_{\text {lyo }}$ showed zero colonies after 30 days at room temperature and retained CFPS viability (Supplementary Figure S2).
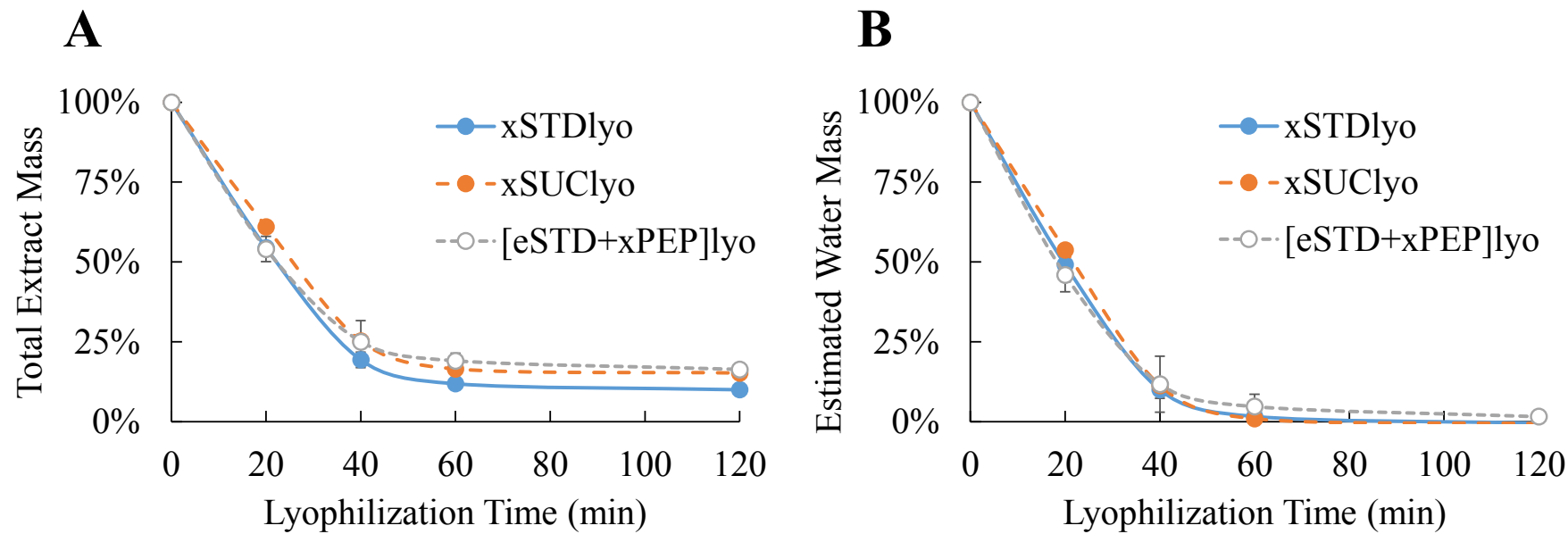

Figure 1. Total mass and estimated water content during lyophilization. (A) The total mass of the extract was monitored throughout the lyophilization process. Extracts lost nearly $80 \%$ of their total mass in the first 40 min of lyophilization. (B) The water content remaining after lyophilization was estimated based on the calculated partial densities of water in the extract solution (Supplementary Material). In all cases, the estimated water content at the end of lyophilization was less than $3 \%$. Error bars represent one standard deviation. $n=3$ for $x S T D_{l y,}, n=2$ for $[x S T D+e P E P]_{l y o}$, and $n=1$ for $x S U C$ 

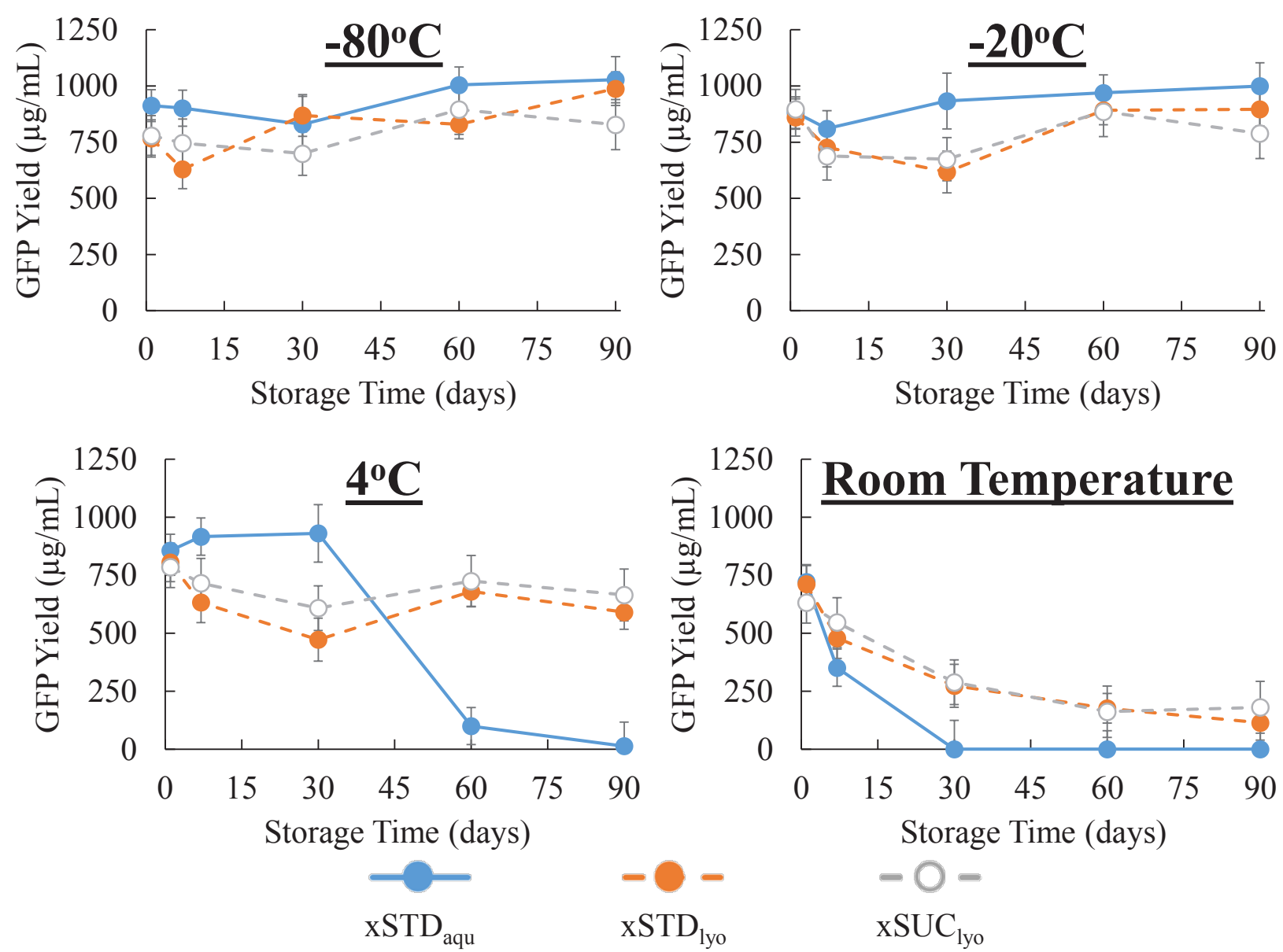

Figure 2. CFPS yields from aqueous and lyophilized extracts stored at various temperatures. Standard storage for extracts is in an ultralow freezer at $-80^{\circ} \mathrm{C}$. Here, extracts were stored at $-80^{\circ} \mathrm{C},-20^{\circ} \mathrm{C}, 4^{\circ} \mathrm{C}$, and room temperature $\left(27^{\circ} \mathrm{C} \pm 3^{\circ} \mathrm{C}\right.$ ). The first data point (day 1$)$ corresponds to one day after lyophilization. Error bars represent one standard deviation of protein yield and error contributed to rehydrating the extracts (Supplementary Material). $n=3$.

Straightforward lyophilization of extracts lays the foundation for high-density and long-term storage of CFPS systems. However, extracts must be provided with an energy source and essential building blocks to successfully transcribe mRNA and translate protein. Typically, energy sources for CFPS are stored as solutions at $-80^{\circ} \mathrm{C}$ due to the temperature sensitive nature of high-energy components such as nucleoside triphosphates, nicotinamide adenine dinucleotide, coenzyme A, and phosphoenolpyruvate (PEP). In powdered formats, high-density mixtures of energy-rich components are less likely to suffer degradation. We therefore considered powdered energy systems as a possible alternative to aqueous storage.

PEP-based energy systems are some of the highest yielding CFPS energy systems $(33,34)$. We developed two PEP-based powdered energy systems: $(i)$ a mix of extract and a PEP-based energy system subsequently lyophilized into powder ([xSTD+ePEP] lyo $)$ and (ii) a powder mix of individual components for a PEP-based energy system
$\left(\mathrm{ePEP}_{\text {pow }}\right)$ (Table 1) (34). To produce $[\mathrm{xSTD}+\mathrm{ePEP}]_{\mathrm{lvo}}$, a $1: 1$ aqueous solution of $\mathrm{xSTD}_{\text {aqu }}$ to ePEP $\mathrm{P}_{\text {aqu }}$ was lyophilized as described above. The resulting powder exhibited a sticky heterogeneity similar to $\mathrm{xSUC}_{\mathrm{ly}} \cdot[\mathrm{xSTD}+\mathrm{ePEP}]_{\mathrm{lyo}}$ was maintained at $-80^{\circ} \mathrm{C}$ or $-20^{\circ} \mathrm{C}$ to mitigate extract degradation effects caused by higher temperature storage, as seen in $\mathrm{xSTD}_{\text {lyo }}$ and $\mathrm{xSUC}_{\text {lyo }}$. ePEP $P_{\text {pow }}$ was stored across all temperatures to check for temperature sensitive degradation specific to the energy system.

The temperature sensitive nature of many ePEP ${ }_{\text {pow }}$ components compelled us to propose a more stable powdered energy system. We consulted the previously reported alternative energy systems consisting of components less sensitive to temperature $(3,28,29,35)$ (Supplementary Material). A powdered glucose-based system $\left(e \mathrm{GLU}_{\text {pow }}\right)$ was selected based on the stability of its components to compare with powdered ePEP ${ }_{\text {pow }}$. Glucose is significantly cheaper than PEP, and glucose-based energy systems have been reported to reduce protein yield expenses compared with
PEP-based systems (3). Also, glucose is quite stable in crystal form. To further increase the stability of the glucose-based system, nucleotide triphosphates were replaced with their monophosphate counterparts.

Rehydrating the powdered energy systems in small volumes made it more challenging to achieve a proper $\mathrm{pH}$. The PEP in ePEP pow has a low pKa, yet remains primarily insoluble below $\mathrm{pH}$ 6. For $[\mathrm{xSTD}+\mathrm{ePEP}]_{\mathrm{lvo}}, \mathrm{pH}$ is addressed prior to lyophilization, and the appropriate $\mathrm{pH}$ and buffer ingredients are adjusted prior to lyophilization. However, $\mathrm{ePEP}_{\text {pow }} \mathrm{pH}$ must be considered at the time of hydration. To address this concern, $\mathrm{NaOH}$ was added to the hydration mix at an optimized level (Supplementary Figure S3).

CFPS using the powdered energy systems initially produced high protein yields, as seen in Figure 3. Indeed, $\mathrm{pH}$-optimized ePEP $P_{\text {pow }}$ outperformed aqueous ePEP ${ }_{\text {aqu. }}$. Comparisons of these two systems' reveal that $\mathrm{pH}$-optimized $\mathrm{ePEP}$ pow has a lower $\mathrm{pH}$ than $\mathrm{ePEP}_{\mathrm{aqu}}$, suggesting that the $\mathrm{ePEP}_{\mathrm{aqu}}$ system would benefit from $\mathrm{pH}$-optimi- 

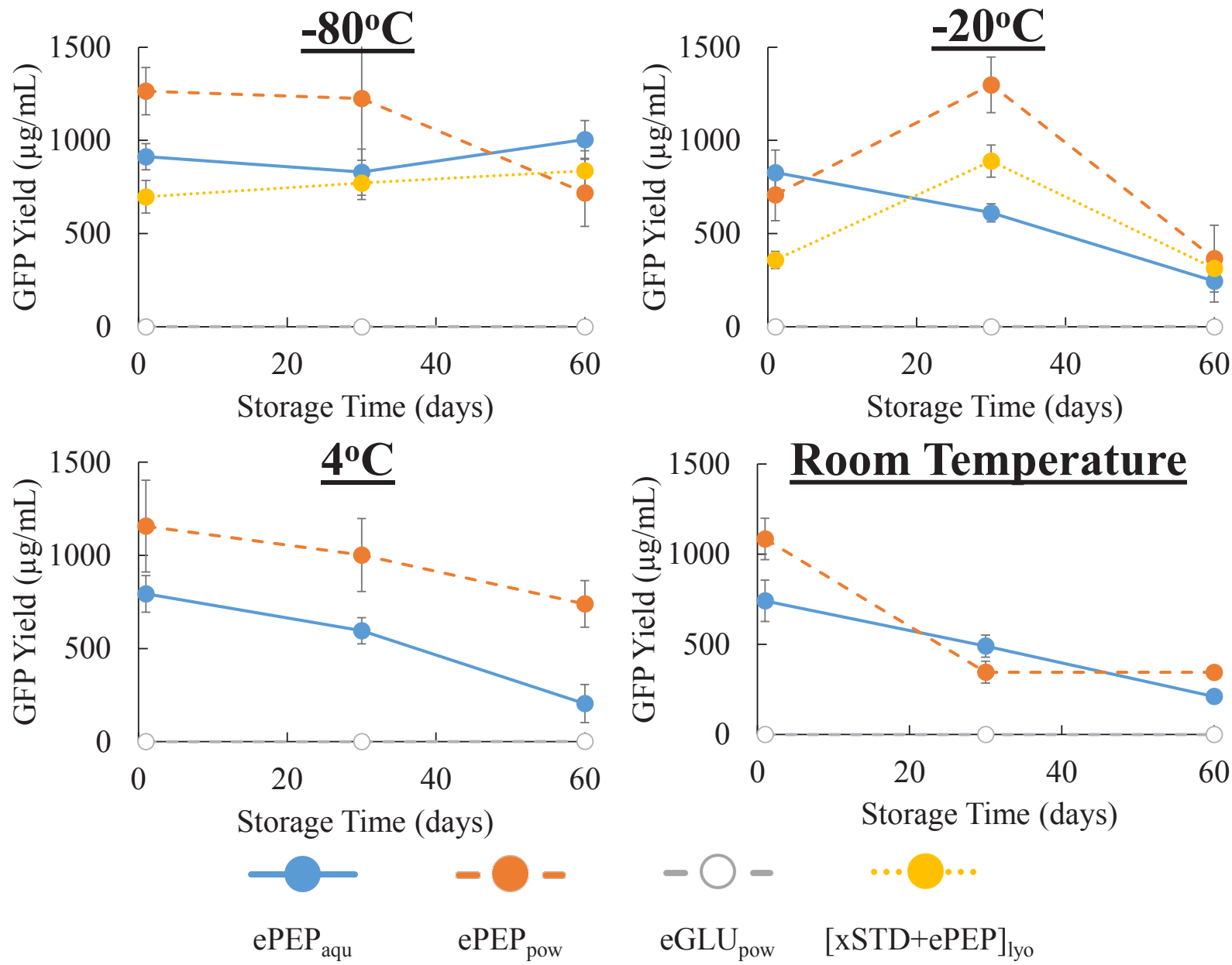

$[\mathrm{xSTD}+\mathrm{ePEP}]_{\text {lyo }}$

Figure 3. CFPS yields from aqueous and powdered energy systems stored at various temperatures. Standard storage for CFPS energy sources is in an ultralow freezer at $-80^{\circ} \mathrm{C}$. Here, systems were stored at $-80^{\circ} \mathrm{C},-20^{\circ} \mathrm{C}, 4^{\circ} \mathrm{C}$, and room temperature $\left(27^{\circ} \mathrm{C} \pm 3^{\circ} \mathrm{C}\right)$ and reacted using $x S T D$ stored at $-80^{\circ} \mathrm{C}$. The first data point (day 1) corresponds to one day after lyophilization or mixing of the powder. Error bars represent one standard deviation of protein yields and error contributed to hydrating the powders. $n=3$.

zation (Supplementary Figure S4). Initial yields from eGLU $\mathrm{pow}$ were very low, totaling less than $5 \%$ of the ePEP $\mathrm{aqu}_{\text {, which was not }}$ unexpected based on previous work (3).

Over the 60 day storage time, $\mathrm{ePEP}_{\text {aqu }}$ performed surprisingly well at elevated storage temperatures, maintaining over $25 \%$ viability at room temperature (Figure 3). This result was unexpected due to the purported instability of its components. eGLU $_{\text {pow }}$ yields remained low throughout storage, but remained relatively consistent with no observable loss in yields, suggesting it is quite stable. However, the low yields produced with eGLU ${ }_{\text {pow }}$ severely limit the utility of such a CFPS system.

The powdered PEP-based energy systems, $[\mathrm{xSTD}+\mathrm{ePEP}]_{\mathrm{lyo}}$ and $\mathrm{ePEP} \mathrm{p}_{\text {pow }}$, maintained a minimum of $35 \%$ of the viability of the $\mathrm{ePEP}_{\text {aqu }}$ over 60 days. Although $[\mathrm{xSTD}+\mathrm{ePEP}]_{\mathrm{lyo}}$ displayed upwards of $95 \%$ viability compared with $\mathrm{xSTD}$ aqu, with ePEP$_{\text {aqu }}$, the lyophilized system exhibited significant inconsistencies in performance. Inconsistent performance of $[\mathrm{xSTD}+\mathrm{ePEP}]$ lyo is likely due to the difficulty in homogenizing the sticky lyophilized powder. ePEP $P_{\text {pow }}$ with optimized $\mathrm{pH}$ performed well over time at all storage conditions. Indeed, at 60 days, $\mathrm{ePEP}_{\text {pow }}$ stored at room temperature retained more than $33 \%$ of its original viability, over $30 \%$ more than $\mathrm{ePEP}_{\mathrm{aqu}}$.

The straightforward methods of extract lyophilization and powdered energy systems presented here allow for high-density storage of eCFPS systems. These powdered systems are also more stable than their aqueous counterparts, permitting $(i)$ more economic storage, (i) simplified transport conditions, and ( $i$ ) a simplified just-addwater protein synthesis system. These benefits make powdered CFPS systems compelling candidates for promising 
applications such as pharmacy-on-a-chip microfluidic devices for rapid on-the-site treatment and rapid large-scale vaccine or therapeutic protein production from stockpiled extract. Indeed, the development of lyophilized extract and powdered energy systems for CFPS reduces the cost, simplifies the procedure, and expands the viable applications of CFPS technology.

\section{Author contributions}

B.C.B. was the principle investigator of this work. M.T.S. was the primary researcher in developing, executing, and analyzing the research performed and was the primary contributor to the drafting of the manuscript. S.D.B. and C.J.W. assisted in obtaining the data reported here and the drafting of the manuscript.

\section{Acknowledgments}

We thank Mike Beliveau (Department of Chemical Engineering, Brigham Young University) for his expertise and advice regarding the lyophilization process and machinery. This work was supported by the National Science Foundation CBET Division CAREER Award (\#1254148), a DARPA
Young Faculty Award (\#D13AP000037), and a BYU Graduate Mentoring Award.

\section{Competing interests}

The authors declare no competing interests.

\section{References}

1. Hodgman, C.E. and M.C. Jewett. 2012. Cell-free synthetic biology: Thinking outside the cell. Metab. Eng. 14:261-269.

2. Swartz, J.R. 2012. Transforming biochemical engineering with cell-free biology. AIChE J. 58:5-13.

3. Shrestha, P., M.T. Smith, and B.C. Bundy. 2014. Cell-free unnatural amino acid incorporation with alternative energy systems and linear expression templates. N Biotechnol. 31:28-34.

4. Arnaz, K.R., J.C. Wu, B.C. Bundy, and M.C. Jewett. 2013. Transforming Synthetic Biology with Cell-free Systems., p. 277-301. In H. Zhao (Ed.), Synthetic Biology: Tools and Applications. Academic Press, Waltham, MA.

5. Carlson, E.D., R. Gan, C.E. Hodgman, and M.C. Jewett. 2012. Cell-free protein synthesis: Applications come of age. Biotechnol. Adv. 30:1185-1194.

6. Smith, M.T., A.K. Hawes, P. Shrestha, J.M. Rainsdon, J.C. Wu, and B.C. Bundy. 2014. Alternative fermentation conditions for improved Escherichia coli-based cell-free protein synthesis for proteins requiring supplemental components for proper synthesis. Process Biochem. 49:217-222.

7. Mureev, S., O. Kovtun, U.T. Nguyen, and K. Alexandrov. 2009. Species-independent translational leaders facilitate cell-free expression. Nat. Biotechnol. 27:747-752.

8. Sun, Z.Z., E. Yeung, C.A. Hayes, V. Noireaux, and R.M. Murray. 2013. Linear DNA for rapid prototyping of synthetic biological circuits in an Escherichia coli based TX-TL cell-free system. ACS Synth Biol. (In press.).

9. Smith, M.T., C.T. Varner, D.B. Bush, and B.C. Bundy. 2012. The incorporation of the A2 protein to produce novel $Q \beta$ virus-like particles using cell-free protein synthesis. Biotechnol. Prog. 28:549-555.

10. Bundy, B.C., M.J. Franciszkowicz, and J.R. Swartz. 2008. Escherichia coli-based cell-free synthesis of virus-like particles. Biotechnol. Bioeng. 100:28-37.

11. Bundy, B.C. and J.R. Swartz. 2010. Sitespecific incorporation of p-propargyloxyphenylalanine in a cell-free environment for direct protein-protein click conjugation. Bioconjug. Chem. 21:255-263.

12. Albayrak, C. and J.R. Swartz. 2013. Cell-free co-production of an orthogonal transfer RNA activates efficient sitespecific non-natural amino acid incorporation. Nucleic Acids Res. 41:5949-5963.

13. Goerke, A.R. and J.R. Swartz. 2009. Highlevel cell-free synthesis yields of proteins containing site-specific non-natural amino acids. Biotechnol. Bioeng. 102:400-416.

\section{Pour Daily Science Fix
Youla}

BioTechniques Newsletters and Alerts complement the print journal by highlighting late-breaking news, feature articles, advanced access to upcoming content, industry events, videos, and more.

Join the more than 80,000 subscribers who receive one or all:

Daily and Weekly Newsletters

- Electronic Table of Contents and BenchTalk Podcast Alerts

- Technology-specific Newsletters

- Cell Analysis/Culture

- DNA Sequencing

- Genetic Engineering Tools \& Techniques

- Genomics/Genetics Tools
- In Vivo Imaging

- PCR/Cloning

- Protein Purification \& Analysis

\section{BioTechniques Newsletters}

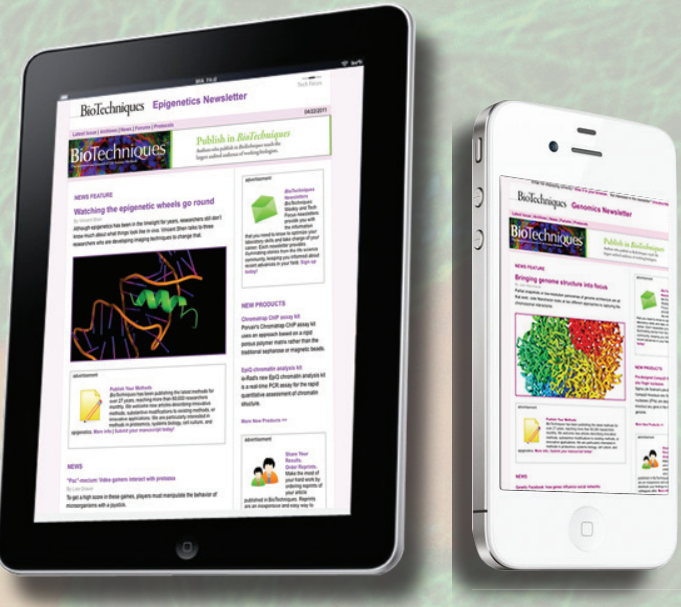


14. Boyer, M.E., J.A. Stapleton, J.M. Kuchenreuther, C.-w. Wang, and J.R. Swartz. 2008. Cell-free synthesis and maturation of $[\mathrm{FeFe}]$ hydrogenases. Biotechnol. Bioeng. 99:59-67.

15. Park, C.G., M.A. Kwon, J.K. Song, and D.M. Kim. 2011. Cell-free synthesis and multifold screening of Candida antarctica lipase B (CalB) variants after combinatorial mutagenesis of hot spots. Biotechnol. Prog. 27:47-53.

16. Kubick, S., J. Schacherl, H. FleischerNotter, E. Royall, L.O. Roberts, and W. Stiege. 2003. In Vitro Translation in an Insect-Based Cell-Free System, p. 209-217. In J. Swartz (Ed.), Cell-Free Protein Expression. Springer Berlin Heidelberg.

17. Kigawa, T., T. Yabuki, N. Matsuda, T. Matsuda, R. Nakajima, A. Tanaka, and S. Yokoyama. 2004. Preparation of Escherichia coli cell extract for highly productive cell-free protein expression. J. Struct. Funct. Genomics 5:63-68.

18. Ma, R., Z. Yang, L. Huang, X. Zhu, L. Kai, J. Cai, X. Wang, and Z. Xu. 2010. Construction of an efficient Escherichia coli cell-free system for in vitro expression of several kinds of proteins. Eng. Life Sci. 10:333-338.

19. Shimizu, Y., A. Inoue, Y. Tomari, T. Suzuki, T. Yokogawa, K. Nishikawa, and T. Ueda. 2001. Cell-free translation reconstituted with purified components. Nat. Biotechnol. 19:751-755.

20. Bundy, B.C. and J.R. Swartz. 2010. SiteSpecific Incorporation of p-Propargyloxyphenylalanine in a Cell-Free Environment for Direct Protein-Protein Click Conjugation. Bioconjug. Chem. 21:255-263.

21. Endo, Y. and T. Sawasaki. 2006. Cell-free expression systems for eukaryotic protein production. Curr. Opin. Biotechnol. 17:373-380

22. Madono, M., T. Sawasaki, R. Morishita, and Y. Endo. 2011. Wheat germ cell-free protein production system for post-genomic research. N Biotechnol. 28:211-217.
23. Martin, G.A., R. Kawaguchi, Y. Lam, A. DeGiovanni, M. Fukushima, and W. Mutter. 2001. High-yield, in vitro protein expression using a continuous-exchange, coupled transcription/translation system. Biotechniques 31:948-953.

24. Kaiser, L., J. Graveland-Bikker, D. Steuerwald, M. Vanberghem, K. Herlihy, and S. Zhang. 2008. Efficient cell-free production of olfactory receptors: detergent optimization, structure, and ligand binding analyses. Proc. Natl. Acad. Sci. USA 105:15726-15731.

25. Blesneac, I., S. Ravaud, C. Juillan-Binard, L.-A. Barret, M. Zoonens, A. Polidori, B. Miroux, B. Pucci, and E. Pebay-Peyroula. 2012. Production of UCP1 a membrane protein from the inner mitochondrial membrane using the cell free expression system in the presence of a fluorinated surfactant. Biochim Biophys Acta. 1818:798-805.

26. Shrestha, P., T.M. Holland, and B.C. Bundy. 2012. Streamlined extract preparation for Escherichia coli-based cell-free protein synthesis by sonication or bead vortex mixing. Biotechniques 53:163-174.

27. Kim, T.-W., H.-C. Kim, I.-S. Oh, and D.-M. Kim. 2008. A highly efficient and economical cell-free protein synthesis system using the $\mathrm{S} 12$ extract of Escherichia coli. Biotechnol Bioprocess Eng 13:464-469.

28. Jewett, M.C. and J.R. Swartz. 2004. Mimicking the Escherichia coli cytoplasmic environment activates long-lived and efficient cell-free protein synthesis. Biotechnol. Bioeng. 86:19-26.

29. Calhoun, K.A. and J.R. Swartz. 2005. Energizing cell-free protein synthesis with glucose metabolism. Biotechnol. Bioeng. 90:606-613.

30. Smith, M.T., J.C. Wu, C.T. Varner, and B.C. Bundy. 2013. Enhanced protein stability through minimally invasive, direct, covalent, and site-specific immobilization. Biotechnol. Prog. 29:247-254.

31. Zawada, J.F., G. Yin, A.R. Steiner, J. Yang, A. Naresh, S.M. Roy, D.S. Gold,
H.G. Heinsohn, and C.J. Murray. 2011. Microscale to manufacturing scale-up of cell-free cytokine production-a new approach for shortening protein production development timelines. Biotechnol. Bioeng. 108:1570-1578.

32. Wang, W. 2000. Lyophilization and development of solid protein pharmaceuticals. Int. J. Pharm. 203:1-60.

33. Albayrak, C. and J.R. Swartz. 2013. Using E. coli-based cell-free protein synthesis to evaluate the kinetic performance of an orthogonal tRNA and aminoacyl-tRNA synthetase pair. Biochem. Biophys. Res. Commun. 431:291-295.

34. Calhoun, K.A. and J.R. Swartz. 2007. Energy Systems for ATP Regeneration in Cell-Free Protein Synthesis Reactions, p. 3-17. In G. Grandi (Ed.), Methods in Molecular Biology. Humana Press, Totowa, NJ.

35. Ahn, J.H., C.Y. Choi, and D.M. Kim. 2005. Effect of energy source on the efficiency of translational termination during cell-free protein synthesis. Biochem. Biophys. Res. Commun. 337:325-329.

Received 20 December 2013; accepted 03 February 2014.

Address correspondence to Bradley C. Bundy, Department of Chemical Engineering, Brigham Young University, Provo, Utah. E-mail: bundy@ byu.edu

To purchase reprints of this article, contact: biotechniques@fosterprinting.com.

\section{horizon}

precision genome editing

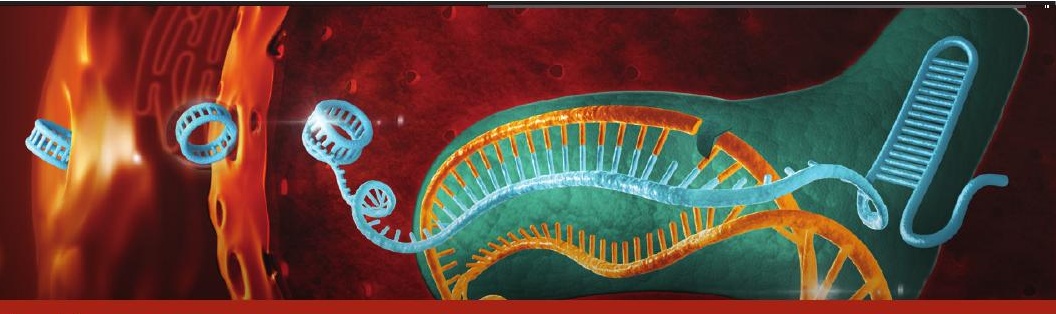

GENASSIST $^{\mathrm{TM}} \mid$ CRISPR \& rAAV Enabled Gene-Editing For Everyone
A range of gene-editing kits and reagents to enable easier, robust

implementation of CRISPR and rAAV gene-editing experiments

\section{Many companies offer CRISPR plasmids, but we offer..}

... Custom RNA Guide manufacturing and Validation

$\checkmark$... Custom Donor Design and manufacturing

... Both CRISPR and rAAV technologies for the right solution to your challenge

$\checkmark$... Adenovirus and rAAV packaging for hard to transfect cells

$\checkmark$... Consultation with our Gene-Editing Expert Scientists

$\checkmark$... Over $\mathbf{5 5 0}$ genetically defined Isogenic Cell Lines available for further genomic modification

.... And an extensive Plasmid Library!

Generate the cell line you want in your lab:

Point Mutations

Insertions

Gene Knockouts
Translocations

Deletions

Amplifications
Visit www.horizondiscovery.com/GENASSIST to learn more about GENASSIST ${ }^{\mathrm{TM}}$ and Horizon's many other products and services 